\title{
The Mediating Role of Procedural Justice in Formalization-Affective Commitment Relationship
}

\author{
Khwanruedee Tuntrabundit ${ }^{1} \&$ Varoon Tuntrabundit ${ }^{1}$ \\ ${ }^{1}$ Faculty of Management Science, Khon Kaen University, Khon Kaen, Thailand \\ Correspondence: Khwanruedee Tuntrabundit, Faculty of Management Science, Khon Kaen University, Khon \\ Kaen, 40002, Thailand. E-mail: Khwtun@kku.ac.th
}

\author{
Received: March 23, 2014 Accepted: April 22, 2014 Online Published: May 30, 2014 \\ doi:10.5539/ass.v10n11p185 URL: http://dx.doi.org/10.5539/ass.v10n11p185
}

\begin{abstract}
This study aims at empirically testing the mediating role of procedural justice in formalization-affective commitment relationship. A questionnaire survey was conducted with 405 full-time employees working in Thailand. A regression analysis was used to test the hypotheses, and Baron and Kenny's (1986) recommendations were employed to explain the mediation hypothesis. The results indicated that the procedural justice mediated the relation of formalization and affective commitment. This study has extended the theoretical knowledge of justice and employee commitment in Thailand's context. In particular, this study examined procedural justice as a mediate variable to analyze the relationship between formalization and affective commitment. The executive can apply the findings of this study to increase employee commitment through clear policy and standard regulations that are applied to everybody in the organization. This will lead to, in the part of the employees, justice and employee commitment.
\end{abstract}

Keywords: formalization, procedural justice, affective commitment, Thailand

\section{Introduction}

In any organization, either public or private sectors, one major factor contributing to employees' long-term working with the organization is employee's commitment. There are different types of commitment, one of which is affective commitment (Meyer \& Allen, 1991; Meyer et al., 2002). Affective commitment is that the employee commits to the organization because he/she "wants to" and he/she feels a strong unity with the work (Katsikea et al., 2011). As such, the employee puts all of effort on the work (Agawam, 1999) and to improve his/her performances (Swailes, 2004; Chen et al., 2011)

Due to the vital role of affective commitment in organizations, there have been a number of research studies in affective commitment, in particular to examine the commitment resulted from the employee's perception on the fairness received by the organization. A recent study examining commitment of staff working in educational institutes and research institutes in Brazil revealed that the staff's desires to work with the organizations increased when they perceived fair assessment and payment (Balassiano \& Salles, 2012). Therefore, employees' perception of procedural justice contributes to affective commitment. This is due to the fact that when working, they need to feel that they are fairly treated and assessed. When they recognize that the level of fairness is low or when the organization does not give good explanations and reasons for the implemented regulations and policy, they do not feel positive rewards, and they are unlikely to dedicate to their work. On the contrary, when perceiving fair regulations and methods, their level of affective commitment is higher (Elanain, 2010). However, even though some previous studies looked at the relationship between procedural justice and formalization (e.g., Andrews \& KacMar, 2001; Ortega et al., 2010), prior empirical research has not examined the mediating role of procedural justice in the formalization-affective commitment relationship. Formalization involves employees' perception on the organization's standard working procedures. Thus, a question arises about whether or not this type of formalization and procedural justice is linked with affective organizational commitment, especially in Thai employees' perceptions. This issue is significant because naturally, when the organization follows standard working procedures, it is clearly shown to the employee that the organization's procedural and assessment criteria are transparent, which increases their perception on the organization's fairness. Therefore, if such relationship is examined, more insights into this issue will be gained and used in the development of a model on how to increase employees' motivation. 
To deeper explain the aforementioned relationship, this study aimed at examining the mediating role of procedural justice and the relationship between formulation and affective commitment in order to extend and add new theoretical knowledge to the previous literatures. Besides, the findings of this study can be used as guidance on policy and regulation development to increase employees' motivation.

\section{The Related Literature and Hypotheses}

Based on literature reviews, this research purposes that formalization will positively associated with procedural justice, and leads to affective commitment. A conceptual model of this research is shown in Figure 1.

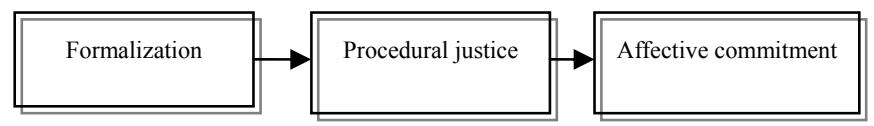

Figure 1. Conceptual model of mediating role of procedural justice

\subsection{Formalization and Procedural Justice}

Formalization is defined as employees' perception on the organization's standard working procedures, which involve rules, regulations, methods, and written working manuals and communication (Schminke et al., 2000). The organization with high formality has highly structural working procedures and monitoring, standard working processes, and transparent policy on assessment and appraisal methods (Ortega et al., 2010; Vosselman, 2012). For example, new employees are oriented about the organization's regulations or are provided with written job descriptions for all positions (Muhammad, 2007). Written documents reveal the organization's high level of formalization (Lin and Germain, 2003). Therefore, clear regulations create a mutual understanding between the organization and the employee, which increases the employee's confidence that they are treated under the same regulation as others. The clearer the regulation, the higher they feel they are treated fairly (Schminke et al., 2000; Ortega et al., 2010). As such, it can be said that employees' perception on the organization's formalization is related to their perception on the organization's procedural justice. Therefore, the hypothesis is proposed as follows:

Hypothesis 1: The formalization will have a positive influence on procedural justice.

\subsection{Formalization, Procedural Justice, and Affective Commitment}

Procedural justice is defined as employees' perception of fairness of methods, policy, or regulation that are used to make decisions on rewarding or working performances of employees in an organization (Lam et al., 2002; Fortin, 2008; Elanain, 2010). Their perceptions are shown through their reaction and behavior. Fairness is considered the consequence of appropriate and correct reaction and working behavior regarding the policy (Stallwarth, 2004; Schermerhorn et al., 2008). In one major study by Mcfarlin and Sweeney (1992), it was found that procedural justice was a variable that could effectively predict the employee's commitment, and the procedure of rewarding criteria development was correlated with his/her perception and understanding of the organization's policy as well as the method employed in decision making.

Affective commitment refers to the employee's emotional attachment to, identification with, and involvement in, the organization, such as being happy to spend the rest of his or her career with this organization, feeling as part of the family at his or her organization, and feeling that the organization has a great deal of personal meaning for him/her (Allen \& Meyer, 1990; Dawley et al., 2008). Thus, affective commitment is selected as an outcome of practical importance (Morrow et al., 2012). Some previous studies showed that commitment is found to arise from perceived fairness (e.g., Magoshi \& Chang, 2009). If organizational procedures are perceived to be fair, employees will be more satisfied, more willing to accept the resolution of that procedure, and more likely to form positive attitudes about the organization (Nabatchi et al., 2007). Furthermore, when the employee believes that decisions are made in a manner that it is procedurally fair, the organizational commitment increases (McFarlin \& Sweeney, 1992; Schminke et al., 2000). Therefore, a high level of perceived procedural fairness may lead to the highest levels of affective commitment. In sum, organizational commitment occurs when the employee compares his/her perceptions on the benefit received from the organization (i.e., output) with their devotion to work (i.e., input) whether the two are balanced. If he/she feels that the output is appropriate or higher, he/she will be satisfied, resulting in his/her perception of fairness and positive attitudes toward their organization.

Therefore, when the employee perceives that the organization has formal rules and procedures that are practiced by all employees in their working and executives in their decision making, he/she perceives and can make 
judgment that the outcome is fair due to the fair rules and procedures and that he/she is not assessed based on the changing situation or the emotion of the appraiser. (Schminke et al., 2000). As such, when the employee perceives procedural justice at work, he or she will feel emotionally attached to the organization, and this is called affective commitment (Magoshi \& Chang, 2009; Wang et al., 2010). Accordingly, it is hypothesized that formalization may be related to procedural justice, and the loss in organization fairness is associated with the employee's low affective commitment. That is procedural justice acts as a mediating variable in formalization-affective commitment relationships. Therefore, the hypotheses are proposed as follows:

Hypothesis 2: The formalization will have a positive influence on affective commitment.

Hypothesis 3: The procedural justice mediates the positive relationship between formalization and affective commitment.

\section{Method}

\subsection{Sample}

The participants of this study consisted of 405 fulltime employees working in the government sector, the private sector, and the state enterprises located in Khon Kaen province, Thailand. 51.9 percent of the participants were government employees; 48.2 percent were private sector employees; the rest were state enterprise employees. All the participants have had worked for at least 1 year in current organization. This cutoff was used to allow time for employees to perceive justice in the organization's practices and to develop commitment to the organization (Magoshi \& Chang, 2009). The research tool was a questionnaire. Since the data were sensitive to the outcome of the participants' performances, all the participants volunteered to take part in this study, the assessment of their fairness on outcome allocation method and policy, and sharing information on the participants' perceptions on the organization's formality, level of organization commitment, and information for all three variables.

\subsection{Measures}

In the conceptual model, all of variables were measured on a five-point Likert's scale, ranging from 1 which represents strong disagreement, to 5 which represents strongly agreement. The procedural justice was used as a mediator in this study. The measurements of dependent, independent, and control variables are described below:

Formalization. This construct is measured by a five-item measure adopted. It was adopted from Andrews \& Kacmar (2001), Muhammad (2007), which is based on previous research by Pugh et al. (1986). The sample items are: "There is a complete written job description for most jobs in this organization"; "This organization has a large number of written rules and policies"; and "There is a formal orientation program for most new members of the organization".

Procedural justice. In this study, the eleven-item measure of procedural justice was used. It was adopted from items used in previous studies (e.g., Schminke et al., 2000; Rhoades et al., 2001) developed by McFarlin and Sweeney (1992). The sample items are: "I feel my organization uses a fair procedure for rating employee performance"; "Decisions in work are usually made consulting the people who have to live with them"; and "I feel organization's procedures are free of bias."

Affective commitment. This construct is measured by a six-item measure adopted from Rhoades et al. (2001), which is adapted from Meyer and Allen (1991). The sample items are "I would be very happy to spend the rest of my life with this organization"; "I feel personally attached to my work at my organization"; and "I enjoy discussing the organization with people outside it."

Control variables. In this study, the control variables were individual demographic variables (i.e., education, age, and tenure in the organization). These variables were found to be statistical controlled in previous research since they may influence the level of affective commitment (e.g., Cole \& Flint, 2004; Magoshi \& Chang, 2009; Elanain, 2010).

\subsection{Data Analysis}

To begin, two experts from the same university were selected to determine measurement items. The results provided support for the efficiency of the questionnaire. Moreover, a questionnaire was administered in person with 30 employees who were not the participants of the study. The reliability of the measurements evaluated using Cronbach alpha coefficients was high showing by Cronbach's alpha coefficient of greater than 0.70 (Nunnally \& Berstein, 1994). The scales of all measures appeared to produce internally consistent results; thus, the reliability of all variables was accepted. To assess the quality of the measure items, the exploratory factor analysis was used to test the construct validity of the measurement model. All factor loadings were greater than the .50 cut-off and were statistically significant $(\mathrm{p}<.01)$ (Hair et al., 2010), no items were eliminated, as such 
providing evidence of measure validation. Furthermore, the results also confirmed content validity. Additionally, confirmatory factor analysis was conducted to test a good representation of the measures. The CFI, TLI, RMSEA, $\chi^{2} / \mathrm{df}$ were reflected adequate levels of fit. These results provided support for the convergent of measurement items, because all factor loading for the underlying constructs were statistically $(p<0.01)$ (Zou et al., 2010). Table 1 shows the results for both loadings scores and reliability.

Table 1. Results of measurement validity and reliability

\begin{tabular}{lcc}
\hline \multicolumn{1}{c}{ Constructs } & Loadings $^{*}$ & Cronbach Alpha \\
\hline Formalization & $.67-.82$ & .86 \\
Procedural justice & $.65-.86$ & .94 \\
Affective commitment & $.55-.97$ & .88 \\
\hline
\end{tabular}

Note. $\mathrm{CFI}=0.97, \mathrm{TLI}=0.96, \mathrm{RMSEA}=0.04, \chi^{2} / \mathrm{df}=1.83$.

Next, a regression analysis was used to test all hypotheses. Based on the meditational procedure suggested by Baron and Kenny (1986), three regression equations were conducted to test a mediation model. The following three conditions must be held: first, the independent variable must significantly affect the dependent variable; second, the independent variable must significantly affect the mediator; and third, the mediator must significantly affect the dependent variable. Moreover, Baron and Kenny suggested that if the effect (i.e. beta weight) of the independent variable on the dependent variable still has significant effect and the effect of independent variable on dependent variable is less in the third equation than in the first, partial mediation is present. If the beta weight of the independent variable has no significant effect in third equation, full mediation (i.e. perfect mediation) is present.

In the present research, the role of procedural justice as a mediator variable in the formalization-affective commitment relationship was tested using a statistical procedure suggested by Baron and Kenny (1986). Therefore, this research conducted a three equations to determine whether the conditions for mediation were satisfied: the independent variable (formalization) must significantly affect the dependent variable (affective commitment); the independent variable (formalization) must affect the mediator (procedural justice); the mediator (procedural justice) must affect the dependent variable (affective commitment) when independent variable (formalization) and the mediator (procedural justice) as predictors.

Finally, Table 2 displays means, standard deviations, and correlation among all variables. Variance inflation factors (VIF) was used to check collinearity among variables. In this research, the VIF values for each independent variable in the models (lowest $=1.008$; highest $=4.071$ ) were below the cut-off of 10 recommended by Hair et al., (2010). That is, multicollinearity did not influence the magnitude of parameter estimates. Accordingly, there were no significant multicollinearity problems in this research.

Table 2. Descriptive statistics and Pearson correlations

\begin{tabular}{lccc}
\hline \multicolumn{1}{c}{ Constructs } & Formalization & Procedural justice & Affective commitment \\
\hline Mean & 3.45 & 3.24 & 3.64 \\
Standard Deviation & .77 & .75 & .69 \\
Formalization & & \\
Procedural justice & $.500^{* *}$ & $.556^{* *}$ \\
Affective commitment & $.447^{* *}$ &
\end{tabular}

\section{Results}

Sample characteristics of the respondents are shown in Table 3. For example, approximately 46.2 percent of tenure in the organization held 1-5 years and only 8.6 percent had 11-15 years. 
Table 3. Characteristics of respondents

\begin{tabular}{lcc}
\hline \multicolumn{1}{c}{ Characteristics } & Frequencies & Percent (\%) \\
\hline Number of respondents & 405 & 100 \\
Age & 76 & 18.8 \\
Less than 26 years old & 182 & 44.9 \\
26-35 years old & 81 & 20.0 \\
36-45 years old & 66 & 16.3 \\
More than 45 years old & & \\
Tenure in the organization & 187 & 46.2 \\
1-5 years & 89 & 22.0 \\
6-10 years & 35 & 8.6 \\
11-15 years & 94 & 23.2 \\
More than 15 years & & \\
Education & 67 & 16.5 \\
Under Bachelor's degree & 260 & 64.2 \\
Bachelor's degree & 78 & 19.3 \\
Higher than undergraduate & & \\
Composition of respondents & 210 & 51.9 \\
Government employee & 42 & 10.4 \\
State enterprise employee & 153 & 37.8 \\
Private employee &
\end{tabular}

Table 4 exhibits hypotheses testing, the results of regression analysis for testing the mediation of procedural justice in the link between formalization and affective commitment. In Model 1, the predictor (i.e. formalization) was entered with the control variables, there appeared that formalization had a positive significant effect on procedural justice $(\beta=.492, \mathrm{p}<.001)$. Therefore, Hypothesis 1 is supported.

Next step, formalization was entered with the control variables in model 2 . The result showed a positive significant effect (direct effect) of formalization on affective commitment $(\beta=.462, p<.001)$, fulfilling the first condition of testing mediation. Therefore, Hypothesis 2 is supported.

Last step, the mediator (i.e. procedural justice) was added into a regression model. In model 3, procedural justice was found to have a significant effect on affective commitment $(\beta=.459, \mathrm{p}<.001)$ and the effect of formalization on affective commitment was smaller $(\beta=.236, p<.001)$ than those in the first step. The results signal a chain of relations where an independent variable affects a mediating variable, which then affects a dependent variable. Thus, the effect of the formalization on affective commitment is reduced when the mediator is introduced. Accordingly, procedural justice partially mediates the relationship between formalization and affective commitment. Therefore, Hypothesis 3 is supported. 
Table 4. Results of regression analysis for testing the mediation effect of procedural justice ${ }^{\text {a }}$

\begin{tabular}{|c|c|c|c|}
\hline \multirow[t]{2}{*}{ Variables } & Formalization & Procedural justice & Affective commitment \\
\hline & Model 1 & Model 2 & Model 3 \\
\hline \multicolumn{4}{|l|}{ Control variables } \\
\hline \multirow[t]{2}{*}{ Age } & -.006 & -.007 & -.004 \\
\hline & $(.011)$ & $(.009)$ & $(.008)$ \\
\hline \multirow[t]{2}{*}{ Tenure } & -.003 & $.023^{* *}$ & $.024^{* *}$ \\
\hline & $(.010)$ & $(.010)$ & $(.009)$ \\
\hline \multirow[t]{2}{*}{ Education } & -.046 & -.015 & .006 \\
\hline & $(.116)$ & $(.119)$ & $(.107)$ \\
\hline \multicolumn{4}{|l|}{ Independent variable } \\
\hline \multirow[t]{2}{*}{ Formalization } & $.492^{* * *}$ & $.462^{* * *}$ & $.236^{* * *}$ \\
\hline & $(.043)$ & $(.044)$ & $(.046)$ \\
\hline \multicolumn{4}{|l|}{ Mediator } \\
\hline \multirow[t]{2}{*}{ Procedural justice } & & & $.459^{* * *}$ \\
\hline & & & $(.046)$ \\
\hline Adjusted $\mathrm{R}^{2}$ & .249 & .213 & .370 \\
\hline
\end{tabular}

\section{Discussion, Conclusion, Contributions and Directions for Future Research}

In this research, we used a quantitative research design to examine the procedural justice as a mediate variable to analyze the relationship between formalization and affective commitment. The results suggest that formalization had a positive significant effect on procedural justice. This result fulfils the second condition of the testing of mediation. The result is similar to those of Andrews and Kacmar (2001) who found that the higher level of formalization were related to the higher level of procedural justice. Ortega et al. (2010) stated that employees perceived formalization from regulations on procedures, rules of behavior, and regulations on the monitoring of work development. In highly formalized systems, there is a complete written job description in an organization, and the organization keeps a written record of nearly everyone's job performance (Muhammad, 2007). They seem to be little flexibility existing in determining what outcomes are. Since procedures and rewards are dictated by the rules, employees are confident that they are being treated the same as others in similar situations (Schminke et al., 2000). Thus, the high level of formalization increases the employee's perception of procedural justice.

Moreover, the result showed a positive significant effect of formalization on affective commitment. This evidence confirmed a causal relationship going from formalization to affective commitment in Auh and Menguc (2007)' study, which argued that formalization indicates a process control which seeks to set standards and rules, thus the employee's behavior does not deviate from the goal of the organization. Thus, he or she has the strongest positive relation ongoing to the goal, feels he/she is part of the family at organization, and is happy to spend the rest of his or her life with the organization. Hence, formalization is a driver in increasing the level of perception of affective commitment.

In addition, we found that procedural justice partially mediates the relationship between formalization and affective commitment. On the procedural justice-affective commitment relationship, this result is consistent with the previous studies which suggested that increasing levels of employee commitment resulted in enlarged perceptions of procedural justice (Magoshi \& Chang, 2009; Wang et al., 2010). The organization that consistently use fair procedures when determining allocation of resources, employees feel job security and feel personally attached to work at their organization (Muhammad, 2007).

In sum, the present research tested the mediation of procedural justice in the link between formalization and affective commitment in the Thailand's context. The results showed that procedural justice helped explain the effect of formalization on organizational commitment and that greater formalization and procedural justice were likely to enhance employees' organizational commitment. 
The results of this research provide a clearer understanding of formalization, procedural justice and affective commitment relationship, both theoretically and managerially. This research contributes to the literature in two ways. First, the model advances theorists' understanding of a formalization-procedural justice relationship, and of a positive perception on procedural justice that it impacts positively on affective commitment. Moreover, the model provides an understanding of the mediation role that procedural justice plays between affective formalization and affective commitment.

The results showed how dangerous the lack of employees' positive perception on procedural justice was on the organization. The results provide evidence to managers that the relationship among formalization, procedural justice, and affective commitment are needed. When formal policies and procedures of organizations are seen as fair, the employees' affective commitment is high because naturally, employees always need to know reasons for the outcome they receive. When they perceive that the reasons are appropriate, they feel attached to the organization and want to put all their effort on work.

To increase the benefits of the study, future research is needed to search for moderating variables such as the quality of employee-organization relationship which should be included in the model, and testing and explaining the role of a moderator in the formalization-procedural justice relationship. Even though the organization's rules and regulations are clear and fair, the relationship between the head and his/her subordinates may positively or negatively influence employees' affective commitment. Moreover, analysis of differences between group means (i.e. government, state enterprise, and private employees) may provide differences in their perceptions.

Additionally, there is the issue of the generalizability of results. This research used the questionnaires for collecting data from employees in Thailand. Therefore, an interpretation of the results should be carefully made, it is important to include participants from different countries in order to confirm the results of this research in future studies. Finally, this research was conducted as a snapshot without considering the dynamic nature of work environment; a longitudinal research design may provide greater insights into this area.

\section{References}

Agawam, S. (1999). Impact of job formalization and administrative controls on attitudes of industrial $\begin{array}{lllll}\text { salespersons. } & \text { Industrial } & \text { Marketing } & \text { Management, } & \text { 28, }\end{array}$ http://dx.doi.org/10.1016/S0019-8501(98)00026

Allen, N. J., \& Meyer, J. P. (1990). The measurement of antecedents of affective, continuance and normative commitment to the organization. Journal of Occupational Psychology, 63, 1-18. http://dx.doi.org/10.1111/j.2044-8325.1990.tb00506.x

Andrews, M. C., \& Kacmar, M. (2001). Discriminating among organizational politics, justice, and support. Journal of Organizational Behavior, 22(4), 347-366. http://dx.doi.org/10.1002/job.92

Auh, S., \& Menguc, B. (2007). Performance implications of the direct and moderating effect of centralization and formalization on customer orientation. Industrial Marketing Management, 36(8), 1022-1034. http://dx.doi.org/10.1016/j.indmarman.2006.02.010

Balassiano, M., \& Salles, D. (2012). Perceptions of equity and justice and their implications on affective organizational commitment: A confirmatory study in a teaching and research institute. BAR, Rio de Janeiro, 9(2), 268-286. http://www.anpad.org.br/bar

Baron, R., \& Kenny, D. (1986). The Moderator-Mediator Variable Distinction in Social Psychological Research: Conceptual, Strategic, and Statistical Considerations. Journal of Personality and Social Psychology. 51(6), 1173-1182. http://dx.doi.org/10.1037/0022-3514.51.6.1173

Chen, T., Wu, P. \& Leung, K. (2011). Individual performance appraisal and appraisee reactions to workgroups: The mediating role of goal interdependence and the moderating role of procedural justice. Personnel Review, 40(1), 87-105. http://dx.doi.org/10.1108/00483481111095537

Cole, N. D., \& Flint, D. H. (2004). Perceptions of distributive and procedural justice in employee benefits: Flexible versus traditional benefit plans. Journal of Managerial Psychology, 19(1), 19-40. http://dx.doi.org/10.1108/02683940410520646

Dawley, D. D., Andrews, M. C., \& Bucklew, N. S. (2008). Mentoring, supervisor support, and perceived organizational support: What matters most? Leadership \& Organization Development Journal, 29(3), 235-247. http://dx.doi.org/ 10.1108/01437730810861290

Elanain, H. M. A. (2010). Testing the direct and indirect relationship between organizational justice and work outcomes in a non-western context of the UAE. Journal of Management Development, 29(1), 5-27. 
http://dx.doi.org/ 10.1108/02621711011009045

Fortin, M. (2008). Perspectives on organizational justice: Concept clarification, social context integration, time and links with morality. International Journal of Management Reviews, 10(2), 93-126. http://dx.doi.org/10.1111/j.1468-2370.2008.00231.x

Hair, J. F., Black, W. C., Babin, B. J., \& Anderson, R. E. (2010). Multivariate Data Analysis. USA: Pearson Education International.

Katsikea, E., Theodosiou, M., Perdikis, N., \& Kehagias, J. (2011).The effects of organizational structure and job characteristics on export sales managers' job satisfaction and organizational commitment. Journal of World Business, 46(2), 221-233. http://dx.doi.org/ 10.1016/j.jwb.2010.11.003

Lam, S. S. K., Schaubroeck, J., \& Aryee, S. (2002). Relationship between organizational justice and employee work outcomes: A cross-national study. Journal of Organizational Behavior, 23(1), 1-18. http://www.jstor.org/stable/4093682

Lin, X., \& Germain, R. (2003). Organizational structure, context, customer orientation, and performance: Lessons from Chinese state-owned enterprises. Strategic Management Journal, 24(11), 1131-1151. http://www.jstor.org/stable/ 20060605

Magoshi, E., \& Chang, E. (2009). Diversity management and the effects on employees' organizational commitment: Evidence from Japan and Korea. Journal of World Business, 44(1), 31-40. http://dx.doi.org/10.1016/j.jwb.2008.03.018

McFarlin, D. B., \& Sweeney, P. B. (1992). Distributive and procedural justice as predictors of satisfaction with personal and organizational outcomes. Academy of Management Journal, 35(3), 626-637. http://dx.doi.org/10.2307/256489

Meyer, J. \& Allen, M. (1991).A three-component conceptualization of organizational commitment. Human Resources Management, 61-89. http://dx.doi.org/10.1016/1053-4822(91)90011-Z

Meyer, J. P., Stanley, D. J., Herscovitch, L., \& Topolnytsky, L. (2002). Affective, continuance, and normative commitment to the organization: A meta-analysis of antecedents, correlates, and consequences. Journal of Vocational Behavior, 61(1), 20-52. http://dx.doi.org/10.1006/jvbe.2001.1842

Morrow, P. C., McElroy, J. C., \& Scheibe, K. P. (2012). Influencing organizational commitment through office redesign. Journal of Vocational Behavior, 81(1), 99-111. http:// dx.doi.org/10.1016/j.jvb.2012.05.004

Muhammad, A. H. (2007). Antecedents of organizational politics perceptions in Kuwait business organizations. Competitiveness Review: An International Business Journal, 7(4), 234-247. http://dx.doi.org/10.1108/10595420710844325

Nabatchi, T., Bingham, L. B., \& Good, D. H. (2007). Organizational justice and workplace mediation: a six-factor model. International Journal of Conflict Management, 18(2), 148-174. http://dx.doi.org/10.1108/10444060710759354

Nunnally, J. C., \& Bernstein, I. H. (1994). Psychometric Theory. NY: McGraw-Hill.

Ortega, E. M. P., Saez, P. Z., \& Cortes, E.C. (2010). Can formalization, complexity, and centralization influence knowledge performance? Journal of Business Research, 63(3), 310-320. http://dx.doi.org/10.1016/j.jbusres.2009.03.015

Rhoades, L., Eisenberger, R., \& Armeli, S. (2001). Affective commitment to the organization: the contribution of perceived organizational support. Journal of Applied Psychology, 86(5), 825-836. http://dx.doi.org/10.1037//0021-9010.86.5.825

Schminke, M., Ambrose, M. L., \& Cropanzano, R. S. (2000).The effect of organizational Structure on Perceptions of Procedural Fairness. Journal of Applied Psychology, 85(2), 294-304. http://dx.doi.org/10.1037/0021-9010.85.2.294

Schermerhorn, J. R., Hunt, J. G., Osborn, R. N. (2008). Organizational Behavior 10/e. USA: John Wiley \& Son Inc.

Stallworth, L. (2004). Antecedents and consequences of organizational commitment to accounting organizations. Managerial Auditing Journal, 19(7), 945-955. http://dx.doi.org/ 10.1108/02686900410549457

Swailes, S. (2004). Commitment to change: profiles of commitment and in-role performance. Personnel Review, 23(2), 187-204. http://dx.doi.org/ 10.1108/00483480410518040 
Vosselman, E. D. J. (2012). Organizational structure, operational coordination and relational signals: How voluntary actions by organizations lead to formal control structures. International Journal of Management, 29(2), 745-759. http://www.questia.com/read/1P3-2689133331

Wang, X., Liao, J., Xia, D., \& Chang, T. (2010). The impact of organizational justice on work performance Mediating effects of organizational commitment and leader-member exchange. International Journal of Manpower, 31(6), 660-677. http://dx.doi.org/ 10.1108/01437721011073364

Zou, H., Chen, X., \& Ghauri, P. (2010). Antecedents and consequences of new venture growth strategy: An empirical study in China. Asia Pacific Journal of Management, 27, 393-421. http://dx.doi.org/10.1007/s10490-009-9157-0

\section{Copyrights}

Copyright for this article is retained by the author(s), with first publication rights granted to the journal.

This is an open-access article distributed under the terms and conditions of the Creative Commons Attribution license (http://creativecommons.org/licenses/by/3.0/). 